\title{
KONSEP BELAJAR MENGAJAR DALAM AL-QUR'AN: TELAAH IMPLIKASI EDUKATIF QS. AL-'ALAQ (96): 1-5
}

\section{Muhammad Taufik*}

\section{Abstract}

The concept of teaching and learning in the al-Qur'an is basically able to, necessary, and must be exploited and developed continuously. This is to take into reality the superiority of the concepts from al-Qur'an and provide appropriate solution to the development of knowledge and science, education and teaching, and learning. In this perspective, as stated in Qs. al-'Alaq (96):1-5, about the decree to learn nobly basically can be viewed as the model of learning which is in line with the model of learning recommended by latest findings of the researches in the field of sciences such as neuropsychology, neurobiology, and neuroscience where the subjects of learners are admitted and respected. Therefore, the command to read followed by the name of the Lord, the Almighty, and the direction or object of learning, contain problematical concepts started from intention and learning nobly and problem solving model which is also valued graciously.

Keywords: Qs. al-'Alaq, Iqra', Belajar, Qalam, Ilmu, Pendidikan.

KONSEP dan makna membaca, belajar-mengajar, dan kemuliaan bagi manusia yang ditunjukkan Qs. al-'Alaq (96): 1-5 seyogyanya memberi inspirasi bagi umat Islam untuk mengembangkan pendidikan yang ideal. ${ }^{1}$ Akan tetapi kenyataannya, jangankan

\footnotetext{
*Penulis dosen di Fakultas Tarbiyah IAIN Mataram. email: taufik_hm25@yahoo.com
} 
mendekati yang ideal, yang terjadi justru sebaliknya, masyarakat kita sedang dalam "penderitaan parah" yang multidimensional. Secara intelektual kita bodoh atau sumberdaya manusia kita rendah, secara sains-teknologis kita ketinggalan, secara materifinansial (meski potensi sumber daya alam kaya) kita miskin, secara spiritual dan sosio-moral kita sangat rendah. Mengapa hal itu terjadi? Secara agak apologis, tentu banyak hal yang bisa dituding sebagai penyebab yang mengantarkan kita ke dalam suasana seperti itu, seperti faktor politik, sistem sosial yang sedang berlaku, sistem hubungan "kita" dengan "mereka" yang tidak pas, sistem pendidikan yang masih belum memadai, dan banyak lainnya. ${ }^{2}$

Di antara beberapa permasalahan yang sedang dihadapi umat Islam di atas, sistem pendidikan menempati posisi yang fundamental. Al-Qur'an menawarkan banyak konsep mengenai pendidikan, misalnya sebagaimana yang terkandung dalam Qs. al-'Alaq (96): 1-5. Di dalamnya terdapat tiga kelompok konsep yang bertalian dengan manusia, yaitu konsep proses dan misi

${ }^{1}$ Dalam mengomentari permulaan surat al-'Alaq tersebut, Muhammad 'Abduh menyatakan bahwa tidak ada penjelasan yang paling memuaskan yang menunjukkan keutamaan baca-tulis serta ilmu pengetahuan dengan segala ragamnya, lebih daripada kenyataan dibukanya kitab Allah serta dimulainya wahyu dengan ayat-ayat yang cemerlang ini. Muhammad 'Abduh, Tafsir Juz. 'Amma: Mubammad 'Abduh, ter. Muhammad Bagir (Bandung: Mizan, 1999), 251.

${ }^{2}$ Menurut Watt dan Hitti penyebabnya adalah akumulasi berbagai faktor seperti politik, ekonomi, dan moral. Lihat W. Montgomery Watt, Kejayaan Islam: Kajian Kritis dari Tokoh Orientalis, ter. Harioni Hadikusumo (Yogyakarta: Tiara Wacana, 1990), 165-6 dan Philip K. Hitti, Dunia Arab: Sejarah Singkeat, ter. Ushuluddin Hutagalung \& ODP. Sihombing (Bandung: Sumur Bandung, t.t.), 241. Tentang hubungan "kita" dengan "mereka" yang tidak pas serta menyangkut moral elit penguasa yang rendah, lihat penyimpulan pandangan tokoh-tokoh kebangkitan Islam yang dirumuskan Ali Rahnema dalam Pioneer of Islamic Revival (London \& New Jersey: Zed Books, 1994), 5. 
penciptaan manusia (علق dan (بق) dansep karakteristik psikofisik (بشر) (بشر)), dan konsep belajar dan

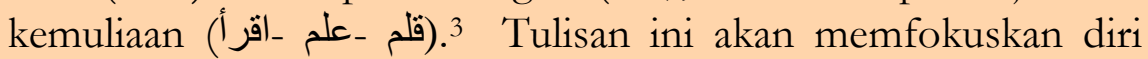
pada konsep yang ketiga, yaitu konsep belajar dan kemuliaan.

\section{Setting Sosio-Historis, Sosio-Kultural dan Psiko-Religius Turunnya Qs. Al-'Alaq (96): 1-5}

Pelacakan atas kondisi sosial-keagamaan dan keilmuan praIslam ${ }^{4}$ bisa dimulai dari dua kawasan yang dipandang sebagai asal dan sumber peradaban manusia, yaitu Mesir Kuno dan Mesopotamia. Secara geografis, Jazirah Arabia Kuno diapit kedua wilayah itu. Sejarah Mesir Kuno bermula dari sebuah peradaban yang terletak di dua tempat, yaitu dataran tinggi yang disebut Mesir Tinggi (Upper Egypt) dan delta sungai Nil yang disebut sebagai Mesir Rendah (Lower Egypt). Masyarakat Mesir Kuno relatif terisolir, dari arah timur dan barat diapit gurun pasir yang ganas, dari arah selatan mengalir sungai Nil yang bermuara ke Laut Mediterania di sebelah utara. Kondisi seperti itu menyebabkan masyarakat Mesir Kuno menjadi satu kesatuan politik yang relatif stabil. Belakangan, masyarakat ini melakukan ekspansi ke Crescent dan Mesopotamia, membuka rute perdagangan melewati gurun pasir ke Laut Merah dan mulai berdagang dengan negara-negara di sekitar samudera India, yang kemudian membawanya kepada kondisi yang tidak lagi terisolir. ${ }^{5}$

3Sayyid Quthb, Fî Zhilâl al-Qur'ân, Juz XXX (Beirut: Dâr Ihyâ al-Turâth al-'Arabî, 1967/1376), 198.

4Permulaan Qs. al-'Alaq (96): 1-5 oleh para mufassir dipandang sebagai permulaan wahyu al-Qur'an yang diterima oleh Rasulullah saw. Lihat Abû Ja'far Muhammad ibn Jarîr al-Thabarî, Jâmi' al-Bayân fî̀ Tafsîr al-Qur'ân (Beirut: Dâr al-Ma'arif, t.t.), 161, Abî Abdillah Muhammad ibn Aḥmad alAnshârî al-Qurthubî, al-Jâmi' li Ahkkâm al-Qur'ân (Beirut: Dâr al-Fikr, t.t.), 105, Quthb, Fî Zhilâl..., juz XIX, 196.

${ }^{5}$ Crane Brinton et.al., A History of Civilization, vol. 1 (New Jersey: Prentice Hall, 1989), 23-4. 
Mesopotamia, derivasi dari term Yunani yang berarti land between rivers, merupakan sebuah kawasan yang terletak di antara dua sungai, Euphrat dan Tigris. ${ }^{6}$ Dalam georafi modern, Mesopotamia adalah di sekitar Irak sekarang. Wilayah tersebut terbentang dalam jalur aliran sungai yang memanjang dari Mesir di barat hingga Tranxoksiana di timur atau dari Nil sampai Oksus. Bagian utara kawasan ini dikelilingi pegunungan Armenia dan bagian selatannya oleh padang pasir Arabia. Karena terletak di jalur aliran sungai, serta gugusannya menyerupai setengah lingkaran, menyebabkan wilayah tersebut menjadi subur dan kondusif bagi kehidupan manusia. Wilayah itu oleh para ahli sejarah kemudian disebut sebgai "kawasan bulan sabit yang subur" (the Fertile Crecent). ${ }^{7}$

Sekitar milenium ketiga sebelum Masehi, terjadi proses suksesi dari Kerajaan Sumeria oleh Kerajaan Akkad, kemudian Kerajaan Asiría, dan Babylonia. Dari sisi keberagamaan, masyarakat ketika itu masih secara perorangan melakukan sesajian (sesembahan) mengikuti pola struktur sosial yang absolute monarchis. Tuhan bagi mereka merupakan representasi dari kekuatan-kekuatan tersembunyi, penting, dan berpengaruh yang mengendalikan alam sekitar di mana dan dengan apa mereka hidup, sehingga dikenal berbagai dewa seperti Dewa Air dan Dewa Angin yang berkaitan dengan agriculture mereka. Di sisi lain, Mesopotamia, daerah bagian utara di kota Harran diinformasikan tentang adanya penduduk yang dikenal sebagai keluarga Ibrani, Ibrahim, Isaac, dan Jacob. Suku Ibrani (Hebrew Race) merupakan suku semi-nomadic yang didirikan Ibrahim sebagai orang pertama yang bermigrasi keluar dari Kan'an

6Dua sungai itu yang disebut dalam Qs. al-Furqân (25) :53 sebagai bạhrayn dan dalam Qs. al-Fâthîr (35): 12 sebagai bahrân yang diberi anotasi oleh Yousuf Ali bahwa Bahrayn: two seas, or two bodies of flowing water; for bahl is applied both to the salt sea and to rivers... Lihat Abdallah Yousuf Ali, The Glorious Qur'an: Translation and Commentary (Beirut: Dâr al-Fikr, t.t.), 53.

${ }^{7}$ Hitti, Dunia ..., 16. 
(Israel-Libanon) ke Mesir, dan pada akhirnya kembali lagi ke Kan'an. Belakangan, suku tersebut diketahui memiliki agama tersendiri, yaitu Yahudi. Sejak bermukim di Kan'an, Ibrahim mendirikan sejumlah "altars" seperti di Hebron, Tejed, dan lainnya. ${ }^{8}$

Kondisi sosio-keagamaan dan kultural masyarakat Mesir Kuno agak berbeda dengan yang ada di Mesopotamia. Hal ini bisa jadi disebabkan karena sejak awal milenium ketiga, bahkan sejak akhir milenium keempat sebelum Masehi, Mesir merupakan kerajaan-kerajaan yang dikuasai oleh berbagai dinasti, dimulai zaman dinasti awal 3100-2686 SM, hingga zaman dinasti akhir 1085-332 SM, kemudian disusul Iskandar Zulkarnain 332323 SM dan Dinasti Ptolemaic 323-30 SM. ${ }^{9}$ Dinasti pertama memiliki pemerintahan yang kuat dengan sistem birokrasi yang terpusat. Merekalah yang telah membangun piramida besar (great pyramid) di Giza. Raja-raja Mesir umumnya sangat egois dan memerintah secara otoriter berdasarkan atau atas nama agama, sehingga rakyat hanya menurut saja. Bahkan di antara rajanya adalah Fir'aun (Pharao) yang menobatkan dirinya sebagai jelmaan Tuhan yang harus ditaati oleh rakyatnya. Fir'aun dipandang sebagai personifikasi Tuhan, yang memiliki kekuasaan tanpa batas. Kepercayaan akan kehidupan kembali setelah kematian juga mulai muncul, yang bisa dibuktikan dengan adanya mumi yang diawetkan di Piramida. Masyarakat Mesir sejak itu telah mempercayai adanya jiwa yang dikandung badan yang mereka namakan ' $k a$ ' suatu kekuatan vital yang menyebabkan manusia bisa hidup. Pandangan mereka tentang jiwa adalah the soul is set free after death, and can also appear as a

${ }^{8}$ Lebih lanjut tentang agama dan kepercayaan masyarakat di sekitar Mesopotamia, lihat Moinuddin Ahmed, Religions of all Mankind (New Delhi: Kitab Bhavan, 1994), 102-1 dan 186-8.

'David O' Connor, "Egypt, Ancient", dalam Grolier Academic Encyclopedia, Grolier International, vol. 7 (t.t.p.: Grolier International, 1983), 82. 
ghost. ${ }^{10}$ Di samping kepercayaan seperti itu, masyarakat Mesir Kuno juga percaya dan menyembah banyak dewa, di antaranya yang dikenal adalah Osiris, Isis, Horus, dan Amon (Among).

Mengenai jazirah Arabia, suatu kawasan luas yang terletak di sebelah barat-daya Asia, di sebelah utara dibatasi padang pasir Syria, sebelah timur Teluk Persia, sebelah selatan Lautan India, dan sebelah barat Laut Merah. Arabia bagian barat sekitar Laut Merah antara Terusan Suez dengan Lautan India yang di antaranya merupakan pegunungan yang dikenal sebagai dataran tinggi Hijaz dan pojok barat-laut dari semenanjung Arabia tersebut dikenal dengan Yemen. Sedangkan dataran rendah dan Hijaz bagian utara memiliki kota-kota yang sudah dikenal secara luas seperti Mekah dan Yatsrib (kini Madinah). Arabia Kuno dihuni oleh berbagai ras, pernah juga dikuasai oleh suku Chaldeans. Mereka pernah mencapai kebudayaan yang tinggi dan pengaruhnya sampai ke Mesir dan Mesopotamia. Tetapi, pada akhirnya kemajuan budaya masyarakat Arab Kuno itu dirusak oleh suku Semit yang datang dari sebelah timur Euphrate, yang dikenal sebagai keturunan Kahtan atau juga disebut Joktan. Kekuasaan Kerajaan Kahtan ini cukup besar, menguasai Yaman dan beberapa bagian lainnya dari Arabia hingga akhir abad VII Masehi. Sedangkan yang terakhir menetap adalah Ishmaelites, Ismail putra dari Ibrahim (the great patriarch of the Jews) tinggal dekat Mekah dan mereka membangun tempat beribadah, yaitu Ka'bah. Dari mereka inilah secara turun temurun kemudian menjadi masyarakat Hijaz dan merupakan pendukung terbesar Arabia.

Meski terdapat pandangan yang menyatakan bahwa secara keseluruhan masyarakat Arab adalah masyarakat besar marginal dan nomadic (pengembara), nampaknya pembagian masyarakat Arab menjadi masyarakat kota (menetap) dan badui (pengembara) menjadi lebih relevan. Sebab, pada kenyataannya,

10Ahmed, Religions..., 195. 
terutama di Arabia bagian selatan terdapat kawasan daerah pertanian yang cukup subur. Bahkan sekitar abad V SM di Ancient South Arabia berkembang beberapa kerajaan, termasuk kerajaan-kerajaan kecil di Arabia bagian utara. Akan tetapi, pada abad-abad VI Masehi, kerajaan-kerajaan tersebut sudah tidak nampak lagi. Hal ini diduga disebabkan karena kerajaan-kerajaan tersebut "tenggelam" dalam pengaruh dua super power yang muncul belakangan, Sasanian dan Byzantine. ${ }^{11}$ Dua kerajaan super power itu merupakan representasi dari dominasi pengaruh Timur dan Barat pada abad-abad menjelang kehadiran Islam. Kerajaan Sasania (Sasanian Empire) yang secara teritorial berbasis di Persia (Iran) membentang dari selatan ke arah utara hingga bertemubatas dengan kerajaan Byzantium (Eastern Roman Empire) di kawasan Armenia, sehingga semenanjung Arabia bagian paling unjung utara terbelah kedalam pengaruh dua super-power itu. Palestina (Jerussalem) dan Damaskus sebagiannya takluk ke Byzantium dan kawasan Euprat (Tigres) takluk ke Sasania. Dengan kondisi seperti itu orang-orang Yahudi yang mulanya bermukim di Palestina (Jerussalem) terdesak mundur ke selatan, sehingga sebagiannya bermukim di Yathrib. Dan orang-orang Kristen yang sebagiannya karena "limpahan" pengaruh Roman Empire (agama resminya Kristen) menyebar sampai ke Mekah. Di sisi lain, agama resmi Kerajaan Sasania adalah Zoroasterian Mazdeans, penyembah Tuhan yang disebut Ahuramazda dan nabi terbesarnya adalah Zoroaster. ${ }^{12}$

Dari sisi sosio-keilmuan Jazirah Arab pada dasarnya telah cukup lama mengenal aksara, khususnya Arabia selatan yang juga

${ }^{11}$ Lihat Patricia Crone, "The Rise of Islam in the World" dalam The Cambridge Illustrated History of the Islamic World, ed. Francis Robinson (London: The Cambridge University Press, 1996), 2-31.

${ }^{12}$ Informasi lebih lanjut tentang kedua kerajaan besar itu serta bagaimana kondisi sosio-religinya, lihat Marshal G.S. Hodgson, The Venture of Islam: Conscience and History in a World Civilization (Chicago \& London: The University of Chicago Press, 1974), 125-8. 
dikenal dengan Himyar. Aksara Arab selatan yang memiliki bentuk monumental dan simetrik, berasal dari adaptasi bahasa Semit tertua yang berkembang dalam masyarakat Kan'an. Tulisan Arab Selatan ini disebut musnad (penyangga), mungkin karena bentuknya yang kaku seperti pilar. Bahasa tersebut merupakan cabang dari keluarga bahasa Arab yang terbagi ke dalam beraneka ragam dialek yang cukup berbeda dengan bahasa Arab utara, yang kemudian menjadi bahasa Arab klasik. Catatancatatan yang sebagian besar digoreskan di atas batu itu kebanyakan berupa ucapan persembahan, nama bangunan, dan juga mencakup hukum, dokumen-dokumen, dan ungkapanungkapan keagamaan. Semua itu memberi kesan tentang kebudayaan yang kaya, yang berkembang di daerah tersebut dan mengendalikan perdagangan dengan India dan negara-negara Mediteranian. Kebanyakan di antara tulisan-tulisan itu berasal dari abad pertama sebelum Masehi. Dalam tradisi Arab berikutnya, Arab selatan memainkan peranan penting sebagai titik awal bagi gerakan-gerakan rakyat di Arab, dan hubungan perdagangan telah membuat orang-orang Arab selatan menjalin hubungan yang berkesinambungan dengan saudara-saudara mereka di utara. ${ }^{13}$

Dari segi keberagamaan, masyarakat Arabia sebelum Islam adalah penganut Yahudi dan Kristen termasuk dalam jumlah banyak. Penganut Yahudi kebanyakan menetap di Madinah sedangkan penganut Kristen menetap di Mekah. Di samping penganut kedua agama tersebut, dalam masyarakat Arabia terdapat penganut agama yang merupakan kombinasi konsep politeistik dan animistik. Mereka menyembah patung-patung batu yang kemudian dikenal dengan berhala. Di Mekah yang merupakan pusat kota, terdapat Ka'bah yang dipandang sebagai the holy temple yang di dalamnya terdapat 360 berhala yang mereka

13J. Pedersen, Fajar Intelektualisme Islam, ter. Alwiyah Abdurrahman (Bandung: Mizan, 1996), 15-6. 
sembah. Di antara berhala yang mereka pandang terpenting adalah al-Lattâ, al-Uzza, dan al-Manât. ${ }^{14}$

Dalam perkembangan lebih lanjut, masyarakat yang bercorak Islam (dalam term Hodgson, "the islamicate society") bukan saja merupakan pewaris langsung, tetapi pada taraf yang penuh arti, penerus positif dari masyarakat-masyarakat sebelumnya di negeri-negeri dari sungai Nil sampai Oksus. Dari sudut geografis dan dalam hal sumber-sumber daya manusia dan material, ia akhirnya menjadi pewaris bagi tradisi-tradisi madani dari orangorang Babylonia Kuno, Mesir, Yahudi, Persia, dan tetanggatetangga mereka yang bermacam-macam. Lebih khusus lagi ia adalah pewaris bagi tradisi-tradisi yang diekspresikan dalam beberapa bahasa Semit dan Iran yang dikembangkan selama berabad-abad yang langsung mendahului Islam, yakni tradisitradisi yang pada gilirannya telah dibangun di atas warisanwarisan yang lebih Kuno. ${ }^{15}$

Pada masa-masa al-Qur'an diturunkan - antara tahun 610632 Masehi- obskurantisme ${ }^{16}$ saintifik masih berlaku, baik di Timur maupun di Barat. Di Perancis contohnya, periode ini kirakira bersamaan dengan masa kekuasaan Raja Dogobert, yakni yang paling akhir dari Merovingian. ${ }^{17}$ Karena itu, keotentikan alQur'an dapat dijamin. Meskipun demikian pada masa-masa itu di dunia sekitar Jazirah Arab memang sedang merajalela berbagai model kejahatan dan tradisi-tradisi yang tidak manusiawi. Di

${ }^{14}$ Lihat Syed Ameer Ali, A Short History af the Saracens (New Delhi: Kitab Bhavan, 1994), 4. Ahmed, Religions..., 156.

15Lihat Hodgson, The Venture..., 103-4.

${ }^{16}$ Obskurantisme: prinsip-prinsip atau praktik kaum obskuran, yakni orang-orang yang menentang kemajuan intelektual dan pembaruan politik atau dapat juga disebut sebagai musuh rasionalisme.

${ }^{17}$ Merovingian adalah dinasti pertama raja Frankish yang memerintah Gaul dari AD 500 - AD 751. Lihat Maurice Bucaillle, Asal-Usul Manusia Menurut Bibel Al-Qur'an Sains, ter. Rahmani Astuti (Bandung: Mizan, 1998), 186. 
samping itu, wilayah ini juga menjadi pusat perdagangan lokal yang menjadi perantara dengan dunia perdagangan global belahan dunia bagian barat yang mulai merosot tajam dan pada saat kondisi itulah al-Qur'an turun.

\section{Konsep Belajar-Mengajar dalam Qs. Al-'Alaq (96):1-5}

Pada prinsipnya, rangkaian wahyu yang pertama diterima Nabi Muhammad saw. ${ }^{18}$ sarat dengan konsep yang bernuansa edukatif, khususnya tentang belajar. Di antaranya إقرا pada ayat pertama dan ketiga, علم pada ayat keempat dan kelima, serta pada ayat keempat dari Qs. al-`Alaq (96).

Dalam mengomentari konsep إقر pada ayat pertama Qs. al'Alaq (96) tersebut, para mufassir umumnya menceritakan dialog yang terjadi antara malaikat Jibril sebagai pembawa wahyu dengan Nabi saw. sebagai penerima wahyu. Hampir secara keseluruhan mufassir memandang Nabi saw. sebagai orang yang tidak pandai membaca, sehingga ketika disuruh "membaca"

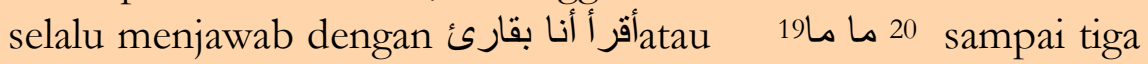
kali. Bahwa Nabi saw. dipandang tidak bisa membaca memang bukannya tanpa alasan. Di samping penjelasan dari Allah swt. dalam Qs. al-'Ankabût (39): 48, ${ }^{21}$ juga dapat dipahami dari makna konsep إقرأ Perintah membaca dalam kata إقرأ tidak hanya ditujukan kepada Nabi secara pribadi semata, tetapi juga kepada manusia umumnya untuk kepentingan kemanusiaannya.

18Secara kronologis disepakati oleh para mufassir bahwa Qs. al-'Alaq (96): 1-5 merupakan wahyu pertama yang diturunkan dan diterima Nabi Muhammad saw. Hal ini disebutkan di hampir keseluruhan kitab tafsir yang menafsirkan surah yang bersangkutan.

${ }^{19}$ Quthb, Fî̀ Zhilâl ..., 197, juga Qurthubî, Al-Jâmi' ..., 108.

${ }^{20}$ Al-Thabarî, Jâmi'..., 161.

${ }^{21}$ Ayat tersebut menjelaskan ketidakmampuan Nabi dalam membaca maupun menulis, sebab bila Nabi bisa membaca dan menulis akan menambah keraguan orang-orang yang tidak beriman. 
Perintah membaca dalam Qs. al-'Alaq (96) juga tidak menegaskan objek yang harus dibaca karena ketika Jibril menyampaikan wahyu tersebut dia tidak membawa tulisan. Jadi, objeknya dapat dipandang "umum" mencakup apa saja yang dapat dijangkau oleh kata tersebut. Dalam hal ini pendapat para mufassir cukup beragam. Al-Thabâthâbaî mengemukakan pandangan tentang إقرا itu bahwa

$$
\begin{aligned}
& \text { المعنى الأول و المر ادبه الأمر بتلقي ما يوحيه إلبه ملك الوحي من القر آن وثنانيا أن } \\
& \text { التقدير اقر أ القرآن او ما في اديه الامن معناه.22 }
\end{aligned}
$$

Pandangan yang sejalan dengan al-Thabathabaî adalah pandangan al-Qurthubî yang menyatakan bahwa ayat itu bermakna:

$$
\text { اقرأ ما نزل إليك من القرآن مفتتحا باسم ربك23 }
$$

Sedangkan menurut Muhammad 'Abduh, perintah membaca ( إقرأ) pada ayat pertama dari wahyu pertama (Qs. al-'Alaq [96]: 1-5) itu termasuk dalam kategori أمرنكوينى yakni perintah Allah untuk menjadikan sesuatu. Nabi saw. ketika itu memang tidak pandai membaca maupun menulis sehingga beliau mengulangulang ucapannya ما أنا بقارئ. Kemudian datanglah perintah Ilabi agar ia menjadi pandai membaca, meski tetap tidak pandai menulis, sebab akan diturunkan kepadanya kitab yang akan dibacanya. Itulah sebabnya ayat tersebut melukiskan Tuhan sebagai "Yang Menciptakan," Zat yang menyandang sifat-sifat yang mampu menanamkan pengaruh-Nya pada segala macam ciptaan-Nya yang tak terhingga, sehingga pastilah Dia mampu juga menciptakan kepandaian membaca.

Dalam perintah membaca pada wahyu pertama yang diturunkan kepada Nabi tersebut, maka seolah-olah Allah swt

${ }^{22}$ Sayyid Husain al-Thabathaba'î, Al-Mîâan fî̀ Tafsîr al-Qur'ân, juz XX (Beirut: Muassasah al-A 'lamî li al-Mathbû' ât, 1141/1991), 370.

${ }^{23}$ Al-Qurthubî, Al-Jâmi'..., 106. 
berfirman kepada Nabi saw. "Jadilah engkau pandai membaca dengan qudrat dan iradat-Ku." 24 Senada dengan itu adalah pandangan al-Ghazali ketika ia menyatakan:

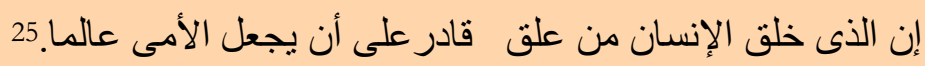

Adapun yang menjadi objek bacaan itu adalah 'nama' (nama Tuhan-mu), sebab 'nama' mengantarkan kepada pengetahuan tentang zat yang punya nama. Akan tetapi -komentar 'Abduh lebih lanjut- apabila kita mengartikan perintah ini sebagai suatu kewajiban yang dibebankan (أمر تكلفى) dengan menyatakan bahwa maknanya adalah bahwa kamu diperintah-ketika membaca sesuatu - agar membacanya dengan nama Allah, maka arti ayat itu adalah apabila kamu membaca, hendaknya kamu selalu membaca dengan pengertian bahwa bacaanmu itu merupakan perbuatan yang kamu laksanakan demi Allah saja, bukan demi sesuatu yang lain. ${ }^{26}$ Kalaupun diperkirakan bahwa seseorang membaca, dengan menjadikan bacaannya itu demi Allah sendiri, bukan demi yang selain-Nya, tetapi ia tidak menyebut nama-Nya, maka ia tetap dianggap membaca demi Allah. Anjuran untuk mengucapkan basmallah dengan lisan, semata-mata guna mengingatkan hati pada permulaan setiap pekerjaan agar senantiasa kembali kepada Allah swt. dalam perbuatan tersebut.

Pengulangan kata إقر pada ayat ketiga dari Qs. al-'Alaq (96) banyak dipandang sebagai ta'kîd dan penyempurnaan kalâm yang kemudian diiringi dengan penyebutan "identitas" Sang Pencipta sebagai Yang Maha Mulia. ${ }^{27}$ Bagi 'Abduh, pengulangan itu merupakan "peyakinan" kepada diri Nabi saw. yang tadinya

24‘Abduh, Tafsir..., 248-9.

${ }^{25} \mathrm{Al}-\mathrm{Ghazâlî,} \mathrm{Tafsîr} \mathrm{Maudlû̀} \mathrm{î} \mathrm{li} \mathrm{Nahwi} \mathrm{Suwari} \mathrm{al-Qur'ân} \mathrm{al-Karîm} \mathrm{(Beirut:}$ Dâr al-Syurûq, 1995), 530.

26'Abduh, Tafsir..., 248-9.

${ }^{27}$ Al-Qurthubî, Al-Jâmi’..., 107. 
tidak bisa membaca, bahwa kini setelah datang perintah yang berulang itu, sungguh-sungguh Nabi saw. menjadi dapat membaca. ${ }^{28}$ Membaca untuk dapat menguasai "pembacaan" itu dalam dunia realitas-historis juga memerlukan pengulanganpengulangan, sehingga sangat dapat dipahami bila pengulangan dalam al-Qur'an dipahami ke arah itu, untuk lebih menguasai dan meyakini kepenguasaan atas suatu kemampuan yang baru diperoleh.

Lalu bagaimana dengan pengertian إقرا I Dalam hal ini para mufassir banyak menyinggung posisi dan fungsi dari إقرأ itu dalam konteks kalimat-kalimat ayat al-Qur'an. Kata إقرأ muncul dalam al-Qur'an sebanyak tiga kali, masing-masing pada Qs. AlIsrâ (17): 14 dan Qs. al-'Alaq (96): 1 dan 3. Sedangkan akar kata tersebut dalam berbagai bentuknya terulang sebanyak 17 kali, selain kata al-Qur'an sebanyak 70 kali. Objek dari kata-kata "membaca" dalam al-Qur'an khususnya yang berakar pada قرأ terkadang menyangkut suatu bacaan yang bersumber dari Tuhan (al-Qur'an atau kitab suci sebelumnya), dan terkadang juga objeknya suatu kitab yang merupakan himpunan karya manusia. ${ }^{29}$ Di sisi lain dapat dipahami bahwa jika sesuatu kata dalam suatu redaksi tidak disebutkan objeknya, maka objek yang dimaksud bersifat umum, mencakup segala sesuatu yang dapat dijangkau oleh kata tersebut. Dari analisis-analisis tersebut bisa dimengerti bahwasanya kata إقرأ dapat dipandang sebagai kata yang mengandung makna yang luas dan beragam, antara lain "menyampaikan, menelaah, membaca, mendalami, meneliti, mengetahui ciri-cirinya, dan sebagainya."30 Jadi, إقرأ adalah memang sangat kental dan sarat dengan muatan konsep belajar

28، Abduh, Tafsir..., 250.

${ }^{29}$ Untuk yang pertama contohnya Qs.Yûnus (10): 94 dan yang kedua contohnya Qs. al-Isrâ’ (17): 14.

${ }^{30}$ Lihat M. Quraish Shihab, Membumikan al-Qur'an (Bandung: Mizan, 1992), 167-171. 
dalam arti yang luas dan mendalam, dan tercakup di dalamnya konsep علم علم dan علم

Term encul dua kali dalam surah al-'Alaq (96) pada ayat keempat dan kelima. Yang pertama dalam arti pengajaran manusia dengan pena dan yang kedua dalam arti pengajaran manusia terhadap hal-hal yang belum diketahuinya, sedangkan قلم muncul hanya sekali pada ayat keempat dalam redaksi:

$$
\text { الذى علم بالقلم -علم الإنسان مالم يعلم }
$$

Al-Thabarî memandang bahwa manusia diajarkan menulis dengan قै di mana qalam merupakan

$$
\text { نعمة عظيمة من الله لو لا ذلك لم يقم ولم يصلح عيش.31 }
$$

Pandangan senada juga dikemukakan oleh al-Qurthubî yang menyatakan bahwa:

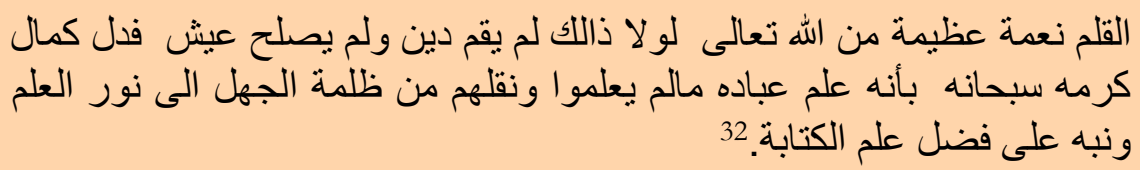

Pentingnya penggunaan qalam dalam pengajaran Tuhan terhadap manusia digambarkan Quthbî bahwa karena qalam masih dan senantiasa berpengaruh luas dan mendalam pada kehidupan manusia sebagai alat pengajaran, yang pada waktu itu kenyataan ini belum nampak dalam kehidupan manusia, tetapi Allah mengetahui arti dan nilai qalam bagi manusia, hingga Dia mengisyaratkan alat ini pada awal permulaan langkah dari langkah-langkah risalah terakhir ini. ${ }^{33}$

Dalam ayat yang sedang dibicarakan ini, kata qalam yang digunakan berarti "alat" tetapi yang dimaksudkan adalah hasil dari kegunaannya, yaitu "tulisan", sebab sulit dibayangkan dan

${ }^{31} \mathrm{Al}$-Thabathaba'î, Al-Mî́ân..., 161.

32Al-Qurthubî, Al-Jâmi'..., 107.

${ }^{33}$ Quthb, Al-Jâmi'..., 202. 
sulit menggambarkan bagaimana terjadinya pengajaran dengan qalam. Untuk lebih dapat dipahami, hal ini perlu dicarikan hubungannya dengan ayat pertama Qs. al-Qalam (68), yang turun persis setelah ayat kelima dari Qs. al-'Alaq (96). Oleh karena itu dapat dipahami bahwa yang dimaksud dengan qalam adalah hasil penggunaan qalam, yaitu tulisan. ${ }^{34}$

Menyangkut bahan ajar yang diajarkan dengan atau dalam proses pembelajaran dengan qalam itu para mufassir berbeda pendapat. Ada yang berpandangan seperti yang telah disinggung di atas, karena objeknya tidak dijelaskan maka itu berarti umum, yaitu apa saja yang dapat dijangkau. Ada pula yang mengkaitkan proses pembelajaran itu dengan pembelajaran Adam oleh Allah ketika hendak dijadikan sebagai khalifah dan digugat oleh Malaikat, yang diceritakan dalam Qs. al-Baqarah (2): 30-34.

Mengenai apa yang diajarkan Allah kepada Adam, sebagaimana yang terkandung dalam penggalan redaksi ayat alQur'an و علم آدم الأسماء كلها para mufassir berbeda pendapat. Bint al-Syâthi' merangkum perbedaan pandangan mufassir tersebut dengan menyatakan bahwa ada yang berpandangan bahwa yang dimaksudkan adalah bahasa, yang berupa hurufhuruf, fi'il-fi'il, dan isim-isim. Ini senada dengan pendapat bahwa nama-nama itu adalah bahasa-bahasa, sehingga termasuk semua bahasa yang digunakan Adam dan anak cucunya. Ada yang menyatakan bahwa yang diajarkan itu adalah nama-nama malaikat. Mufassir lain menggeneralisir ke dalam nama semua benda, seperti unta, kambing, tikus, dan lainnya. Ada menambahkan dengan nama jin dan binatang liar, serta nama anak cucu Adam. Ada pula yang menyatakan bahwa Allah mengajarkan nama-nama benda dengan segala sifat, manfaat benda-benda tersebut bagi keagamaan dan keduniaan. ${ }^{35}$

\section{${ }^{34}$ Ibid., 28.}

${ }^{35}$ Aisyah Abdurrahman (Bint al-Syâthi'), Manusia: Sensitivitas al-Qur'an, ter. M. Adib al-Arief (Yogyakarta: LKPSM, 1997), 42-3. 
Merujuk kepada al-Zamakhsyarî, Bint al-Syâthi' menyatakan bahwa kekhalifahan dan potensi ilmiah yang dimiliki Adam itu juga berlaku untuk semua manusia, karena ungkapan-ungkapan malaikat dalam ayat bersangkutan adalah tentang sifat manusia dalam bentuk jama'. Juga karena yang diserahi kekhalifahan itu semua manusia, maka semua manusia juga dibekali dengan kekuatan ilmiah. Dari sekian pandangan para mufassir yang dicermatinya, Bint al-Syâthi' kemudian menyimpulkan bahwa penghormatan kepada manusia pertama, seperti terungkap dalam perintah Allah kepada malaikat untuk bersujud kepadanya, jelas merupakan kelebihan Adam, karena hanya dia yang mampu menggali pengetahuan yang malaikat tidak mampu mengetahuinya, dan keberpengetahuan inilah ternyata yang merupakan argumen utama dari penunjukan Adam sebagai khalifah-Nya. ${ }^{36}$

Dari analisis tentang proses penciptaan manusia diketahui bahwa sesungguhnya dalam diri manusia telah tersedia potensi jasadiah dan rohaniah, potensi mental-spiritual serta rasionalintelektual yang dapat menjadi fasilitas-fasilitas utamanya dalam proses menjadi berpengetahuan dalam proses belajar. Kemudian dari analisis tentang karakteristik manusia juga diketahui bahwa dalam diri manusia terdapat potensi positif di samping potensi negatif yang akan saling bersaing dalam merebut pengaruh terhadap diri manusia. Perebutan pengaruh (positif-negatif) ini akan terus berlangsung dalam diri manusia tanpa henti sepanjang karier kehidupannya, dan itulah ujian yang harus selalu ditempuh manusia, bahkan hingga kematiannya, untuk mencapai predikat siapa yang paling unggul. ${ }^{37}$ Untuk mencapai kepentingan yang disebut terakhir pun sangat memerlukan proses belajar dan relajar pada diri manusia.

${ }^{36}$ Ibid., 46-9.

${ }^{37}$ Qs. al-Mulk (67): 2. 
Implikasi Edukatif Konsep Belajar Mengajar dalam Qs. al'Alaq (96)

Dunia belajar-mengajar dewasa ini -seiring dengan perkembangan ilmu pengetahuan dan teknologi yang mampu dicapai manusia, khususnya tentang dirinya sendiri seperti fisiologi, biologi, psikologi, psikoterapi, dan lainnya- telah berkembang cukup pesat. Sistem pendidikan konvensional, yang mengandaikan guru (pengajar) sebagai yang serba tahu, yang berkuasa (pemegang otoritas) dan murid (si-belajar) sebagai serba tidak tahu, yang dikuasai (tak berdaya), sudah tidak lagi mampu memberi kontribusi bagi kemajuan kemanusiaan, tetapi justru menjadikan kreativitas pemikiran peserta didik terhadap suatu objek pembelajaran cenderung terbelenggu, sehingga proses belajar-mengajar dalam sistem pendidikan konvensional ini menjadi tidak efektif, dan karenanya secara bertahap sudah mulai ditinggalkan.

Dalam dunia pendidikan dan dunia belajar mengajar gaya lama, murid atau si belajar cenderung dipandang sebagai "bejana" yang kosong dan siap diisi, sehingga mengajar dipahami sebagai "proses menanamkan pengetahuan kepada anak atau proses penyampaian kebudayaan kepada anak." Padahal murid adalah manusia yang "utuh" yang punya perasaan dan punya "aku" dan karenanya punya "harga diri" seperti halnya guru. Jadi, seyogyanya murid tidak diperlakukan sebagai "pesakitan" yang selalu menjadi ajang untuk melampiaskan tempat salah dan kemudian memberinya yang "benar dan baik", atau seyogyanya murid tidak lagi diperlakukan sebagai "bawahan" yang siap diperintah dan bahkan dikuasai oleh sang guru. Dalam konteks ini kiranya tepat perumpamaan yang diungkapkan seorang pendidik Rusia yang menyatakan "mahasiswa ataupun murid (si- 
belajar) bukanlah kendaraan yang akan dan harus diisi, melainkan suatu lampu yang harus dinyalakan." 38

Hasil-hasil penelitian mutakhir di bidang sains humanistik menunjukkan bahwa dalam diri manusia tersimpan potensi dan kekuatan yang luar biasa besarnya, yang batas akhirnya belum dapat diketahui dengan jelas. Melalui rangkaian penelitian dan pengalaman empiriknya, Anthony Robbins kemudian melaporkan banyak hal tentang kekuatan manusia, yang melampaui batas-batas yang terlihat secara empiris. Di antara sekian banyak temuannya itu tercemin dalam ungkapan bahwa "Kalau Anda hanya dapat mencintai, Anda dapat menjadi orang yang paling kuat di dunia." 39 Penelitian di bidang psikologi keberhasilan menunjukkan bahwa keberhasilan seseorang yang berhasil, ditentukan IQ tidak lebih dari $25 \%$ dan lainnya adalah emosi. ${ }^{40}$ Demikian pula penelitian-penelitian di bidang neurobiologi-neurosains telah banyak mengungkapkan bahwa sesungguhnya besaran potensi manusia hingga saat ini belum terdeteksi secara memadai. Sebagai contoh, potensi manusia yang terkandung dalam "otak" nya saja sedemikian besar hingga disebut dengan istilah "the sleeping giant" (raksasa tidur), "alam semesta setengah kilo", "makhluk satu triliyun sel", "perpustakaan terbesar yang pernah ada" dan sebagainya. ${ }^{41}$

38J.A. Battle dan R.L. Shannon, Gagasan Baru dalam Pendidikan ter. Sans S. Hutabarat (Jakarta: Mutiara, 1982), 16.

${ }^{39}$ Untuk hal dimaksud dapat dilihat pada Anthony Robbins, Unpower Limit: Kekuatan Tanpa Batas ter. T. Zaini Dahlan Jakarta: Pustaka Delapratasa, 2000), 367.

${ }^{40}$ Lihat Sharon Bigley, resensi hasil penelitian Daniel Golleman "Working With Emotional Intellegence: The Boss Feels Your Pain: At Work, Emotional Intellegence makes a Difference", dalam Newsweek, 19 Oktober 1998, 51.

${ }^{41}$ Lihat Tony Buzan, Memahami Peta Pikiran ter. Alexander Sindoro (Batam Centre: Interaksara, 2004), 34-40 dan juga Taufiq Pasiak, Membangunkan Raksasa Tidur (Jakarta: Gramedia Pustaka Utama, 2004), 2-7. 
Merespons semuanya itu, kini telah bermunculan gagasangagasan baru dalam pendidikan, khususnya tentang interaksi edukatif dalam proses belajar mengajar. Di antaranya yang dikenal dengan Student Active Learning ( $S A L)$ atau di Indonesia dikenal dengan "Cara Belajar Siswa Aktif (CBSA)", di mana guru dan muridnya sekaligus sama-sama aktif. Sebab yang belajar adalah murid, jadi dia harus aktif. Penghargaan atas "keberadaan" si belajar dalam proses belajar adalah merupakan sesuatu yang "niscaya" dalam pendidikan yang diharapkan dapat berhasil secara efektif.

Pada suatu konferensi pendidikan internasional yang diselenggarakan UNESCO dikeluarkan sebuah rekomendasi, yang diantaranya menyangkut hubungan guru-murid. Di situ dinyatakan bahwa efektivitas pendidikan sekolah sebagian besar tergantung dari perkembangan hubungan baru antara guru dan muridnya, yang menjadi partner yang semakin aktif di dalam proses pendidikan. ${ }^{42}$

Dalam menyikapi perkembangan-perkembangan yang terjadi secara tanpa henti itu, memang banyak model pendidikan dan khususnya proses belajar yang ditawarkan sebagai hasil dari penelitian yang dilakukan secara terus menerus. Di antaranya adalah konsep "pendidikan pembebasan" yang ditawarkan Paulo Freire. ${ }^{43}$ Ia menghadapkan konsep tersebut dengan konsep pendidikan konvensional yang disebutnya dengan pendidikan "gaya bank" yang mengandaikan murid sebagai "bejana" yang "nrimo", yang siap diisi seperti halnya mengisi "celengan" atau tabungan. Menurutnya, pendidikan model ini hanya akan menghasilkan manusia-manusia yang "terpola", manusiamanusia yang "jinak", manusia-manusia yang "penurut" dan mudah dieksploitasi oleh kepentingan yang pro status quo.

${ }^{42}$ Norman M. Goble, Perubahan Peranan Guru, ter. Suryatin Jakarta: Gunung Agung, 1983), 201.

43Paulo Freire, Pendidikan Kaum Tertindas, ter. Utomo Dananjaya dkk. (Jakarta: LP3ES, 1972), 61. 
Bagi Freire pendidikan yang membebaskan, dus pendidikan yang efektif adalah berisi laku-laku pemahaman (acts of cognition), bukannya pengalihan informasi. Untuk itu proses pendidikan harus merupakan proses hadap-masalah (problem-pacing), dialog antar guru, murid dengan murid, guru dengan murid, sehingga muncul suasana baru: guru yang murid dan murid yang guru. Guru tidak lagi menjadi orang yang mengajar dan murid tidak lagi menjadi orang yang diajar. Tetapi, guru mengajar dirinya sendiri melalui dialog dengan murid yang pada gilirannya juga mengajar. Mereka semua bertanggung jawab secara bersama terhadap suatu proses dalam mana mereka tumbuh dan berkembang untuk kepentingan manusia dan kemanusiaan yang lebih luas. ${ }^{44}$

Konsep pendidikan, khususnya tentang proses belajarmengajar, sebagaimana dikembangkan dalam "pendidikan pembebasan", dan juga penemuan-penemuan mutakhir di bidang pendidikan, secara umum terdapat kesearahan dengan konsep yang telah diintrodusir jauh sebelumnya dalam alQur'an. Untuk menyebut contoh adalah dialog antara Ibrahim dengan putranya Ismail di seputar "mimpi-benar" sang ayah. Ibrahim tidak memaksakan kehendaknya untuk melakukan "mimpi-benar" itu, tetapi bertanya dan berdialog secara elegan, sangat demokratis, dan terbuka terlebih dahulu dengan sang putra. ${ }^{45}$ Kenapa di dalam ruang-ruang kelas belajar tidak dirancang-bangun pola hubungan pendidik-peserta didik yang semacam itu? Demikian pula signal yang ditunjukkan tentang konsep belajar-mengajar yang bisa dipahami dari Qs. al-'Alaq (96): 1-5 sesungguhnya juga dapat dipandang sebagai model belajar hadap-masalah, di mana perintah membaca diiringi dengan arah atau objek (menurut sebagian mufassir) yang harus dipahami, sarat dengan konsep-konsep problematis, penuh

${ }^{44}$ Ibid., 62-70.

${ }^{45}$ Qs. al-Shâffât (37): 102. 
dengan muatan-muatan beragam permasalahan, mulai dengan niat dan lakon pembelajaran yang harus dengan kemuliaan serta model pemecahan persoalan yang juga harus bernuansa dan bernilai mulia dan seterusnya.

\section{Catatan Akhir}

Konsep belajar mengajar yang diintrodusir al-Qur'an secara doktrinal sangat tegas sejak awal, yaitu untuk mempersiapkan dan mendukung realisasi kemuliaan yang pada dasarnya merupakan dasar yang inheren dengan keseluruhan semangat alQur'an. Dengan demikian secara asasi, konsep belajar mengajar dalam al-Qur'an sebenarnya dapat, perlu, dan harus digali dan dikembangkan secara terus menerus dalam rangka mewujudkan dan mengembangkan pendidikan yang ideal. Di satu sisi, upaya itu sekaligus untuk mewujud-nyatakan keunggulan konsepkonsep al-Qur'an, dan di sisi lain untuk menyediakan jawaban yang memadai bagi pengembangan ilmu pengetahuan, pendidikan, dan belajar mengajar yang mulia guna menopang kepentingan, kemuliaan penciptaan, dan misi manusia dan kemanusiaan ke depan.

Demikian pula sinyal yang ditunjukkan konsep belajarmengajar yang bisa dipahami dari Qs. al-'Alaq (96): 1-5 sesungguhnya juga dapat dipandang sebagai model atau konsep belajar yang selaras dengan model-model belajar yang direkomendasikan oleh hasil-hasil penelitian mutakhir di bidang neuropsikologi-neurobiologi dan neurosains. Seperti model belajar demokratis-dialogis, "problem facing" (hadap-masalah), "teacher-student partnership" (kesetaraan guru-peserta didik), dalam nuansa saling mengakui dan menghargai antarpihak yang terlibat dalam pembelajaran. Dengan demikian perintah membaca yang diiringi penyebutan nama Tuhan Yang Maha Mulia, serta diiringi dengan arah atau objek (menurut sebagian mufassir), sesunguhnya sarat dengan konsep-konsep problematis, muatan- 
muatan beragam permasalahan, mulai dengan niat dan lakon pembelajaran yang harus dengan kemuliaan serta model pemecahan persoalan yang juga harus bernuansa dan bernilai mulia dan seterusnya.

Dalam perspektif seperti itu sesungguhnya al-Qur'an melalui pesan yang diintrodusir dalam Qs. al-'Alaq (96): 1-5 tentang perintah belajar dan sekaligus melakukan pembelajaran secara mulia pada dasarnya dapat dipandang sebagai wanti-wanti Allah swt. kepada hamba-Nya, bahwa manusia bila hendak dan berambisi dalam mencapai keberhasilan atau kesuksesan dalam kehidupannya, baik sebagai makhluk manusiawi maupun sebagai khalifah dan sekaligus hamba Allah swt., maka hendaknya ia mempersiapkan diri terlebih dahulu dengan secara sebaikbaiknya.

\section{Daftar Pustaka}

Abdallah Yousuf Ali, The Glorious Kur'an: Translation and Commentary (Beirut: Dâr al-Fikr, t.t.).

Abî Abdillah Muhammad ibn Aḥmad al-Anshârî al-Qurthubî, al-Jâmi' li Ahkâm al-Qur'ân (Beirut: Dâr al-Fikr, t.t.).

Abû Ja'far Muhammad bin Jarîr al-Thabarî, Jâmi' al-Bayân fi Tafsîr al-Qur'ân (Beirut: Dâr al-Ma'arif, t.t.).

Aisyah Abdurrahman (Bint al-Syâthi'), Manusia: Sensitivitas alQur'an, ter. M. Adib al-Arief (Yogyakarta: LKPSM, 1997).

Al-Ghazâlî, Tafsîr Maudlû̀ li li Nabwa Suwari al-Qur'ân al-Karîm (Beirut: Dâr al-Shurûq, 1995).

Ali Rahnema, Pioneer of Islamic Revival (London \& New Jersey: Zed Books, 1994).

Amir Syakib Arsalan, "Apa sebab kita mundur?” dalam Islam dan Pembaruan, ed. John D. Donohue \& John L. Esposito, ter. Machnun Husein (Jakarta: Raja Grafindo Persada, 1995). 
Anthony Robbins, Un limit Power: Kekuatan Tanpa Batas, ter. T. Zaini Dahlan (Jakarta: Pustaka Delapratasa, 2000).

Crane Brinton (et.al.), A History of Civilization, vol.1 (New Jersey: Prentice Hall, 1989).

David O. Connor,'. "Egypt, Ancient", dalam Glorier Academic Encyclopedia, Glorier International, vol. 7 (t.tp.: Grolier International, 1983).

J.A. Battle dan R.L.Shannon, Gagasan Baru dalam Pendidikan, ter. Sans S. Hutabarat (Jakarta: Mutiara, 1982).

M. Quraish Shihab, Membumikan al-Qur'an (Bandung: Mizan, 1992).

Marshal G.S. Hodgson, The Venture of Islam: Conscience and History in a World Civilization (Chicago \& London: The University of Chicago Press, 1974).

Maurice Bucaille, Asal-Usul Manusia Menurut Bibel Al-Qur'an Sains, ter. Rahmani Astuti (Bandung: Mizan, 1998).

Moinuddin Ahmed, Religions of All Mankind (New Delhi: Kitab Bhavan, 1994).

Muhammad 'Abduh, Tafsir Juz 'Amma: Mubammad Abduh, ter. Muhammad Bagir (Bandung: Mizan, 1999).

Norman M. Goble, Perubahan Peranan Guru, ter. Suryatin (Jakarta: Gunung Agung, 1983).

Patricia Crone, "The Rise of Islam in the World" dalam The Cambridge Illustrated History of the Islamic World, ed. Francis Robinson (London: The Cambridge University Press, 1996).

Paulo Freire, Pendidikan Kaum Tertindas, ter. Utomo Dananjaya dkk. (Jakarta: LP3ES, 1972).

Philip K. Hitti, Dunia Arab: Sejarah Singkat, ter. Ushuluddin Hutagalung \& ODP. Sihombinmg (Bandung: Sumur Bandung, t.t.)

Sayyid Husain al-Thabâthâba'î, al-Mǐzân fi Tafsîr al-Qur'ân, juz

XX (Beirut: Muassasah al-A 'lamî li al-Mathbû'ât, 1141/1991). 
Sayyid Quthb, Fî Zhilâl al-Qur'ân, juz XIX (Beirut: Dâr Ihyâ alTurâth al-'Arabî, t.t).

Sharon Bigley, "The Boss Feels Your Pain: At Work, Emotional Intellegence Makes A Difference", dalam Newsweek, 19 Oktober 1998.

Syed Ameer Ali, A Short History af the Saracens (New Delhi: Kitab Bhavan, 1994).

Taufiq Pasiak, Membangunkan Raksasa Tidur (Jakarta: Gramedia Pustaka Utama, 2004).

Tony Buzan, Memahami Peta Pikiran, ter. Alexander Sindoro (Batam Centre: Interaksara, 2004).

W. Montgomery Watt, Kejayaan Islam: Kajian Kritis dari Tokoh Orientalis, ter. Harioni Hadikusumo (Yogyakarta: Tiara Wacana, 1990). 